\title{
Komunikasi Pemasaran Geopark Berbasis Masyarakat Melalui Bauran Facebook, Youtube dan Kanal TV
}

\author{
Aris Raharjo \\ Universitas Jenderal Soedirman Purwokerto \\ magikomaris@gmail.com
}

\begin{abstract}
ABSTRAK
Paper ini mengulas pengembangan komunikasi pemasaran pariwisata geopark berbasis masyarakat di desa Peniron Kecamatan Pejagoan Kabupaten Kebu-men. Desa Peniron yang menghadapi sejumlah keterbatasan berhasil mencapai tujuan pemasaran tahap demi tahap setelah mengembangkan komunikasi pema-saran melalui bauran media sosial Facebook, YouTube, dan media tradisional TV secara tanpa bayar. Bauran elemen komunikasi tersebut memberikan efek pada wisatawan untuk berwisata, sehingga desa pertanian tersebut berubah menjadi desa wisata yang memberi manfaat ekonomi baru bagi masyarakat lo-kal, konservasi alam, dan pembangunan berkelanjutan.
\end{abstract}

Kata kunci : geopark, komunikasi pemasaran, Facebook, YouTube, televisi, efektifitas

\section{KATA PENGANTAR}

Komunikasi adalah proses menyampaikan pikiran dan berbagi makna di antara individu atau organisasi dimana dalam prosesnya membutuhkan saluran. Prinsip tersebut tentu berlaku pada komunikasi pemasaran wisata geopark yang kini tengah menjadi tren di industri pariwisata kontemporer. Sehingga tujuan komunikasi pemasaran tentu hanya tercapai jika ada kesamaan makna antara warga selaku komunikator pemasaran dengan wisatawan sehingga memutuskan untuk berwisata di geopark, setelah 
menerima infor-masi dari bauran komunikasi melalui beragam media yang berupa media baru dan me-dia tradisional.

Menurut badan dunia UNESCO (2006), geopark merupakan model pembangunan berkelanjutan yang memiliki nilai-nilai khusus yang terkait dengan pendidikan, ilmu pengetahuan, budaya, dan pembangunan sosial ekonomi, terutama melalui pariwisata dalam bentuk geowisata. Menurut Miśkiewicz (2014) seiring konsep geopark, UNESCO mempromosikan geoheritage dalam bentuk geoproduk, menandai arah komersial untuk menyampaikan pengetahuan tentang geosains. Menurutnya geopark secara global adalah bagian dari identitas regional, pembangunan berkelanjutan, dan merupakan suatu elemen pendidikan.

Neda Torabi Farsani,at. all (2010) dalam penelitian berjudul, "Geotourism and Geo-parks as Novel Strategies for Socio economic Development Rural Areas, "menyatakan geopark merupakan inovasi untuk perlindungan alam, dan warisan geologis yang meng-hasilkan peluang pekerjaan baru, kegiatan ekonomi baru, dan sumber pendapatan tambahan bagi masyarakat di pedesaan. Shander (2016) mengatakan kegiatan geopak mem-berikan impak sosial ekonomi pada masyarakat lokal sehingga terjadi konservasi alam, dan pembangunan berkelanjutan.

Komunikasi pemasaran geopark ini menarik untuk dikaji karena merupakan inovasi pariwisata berbasis masyarakat. Bagi masyarakat desa berkomunikasi dengan wisata-wan yang berbeda negara, dan budaya tentu tidak mudah dan belum menjadi hal biasa, termasuk penggunaan media sosial sebagai alternatif komunikasi pemasaran. Paradigma geopark yang partisipatif mengharuskan peran serta masyarakat termasuk dalam pemasaran. Menurut (Tosun, 2000) partisipasi masyarakat dalam pengembangan pari-wisata di suatu negara memiliki tiga hambatan yaitu keterbatasan operasional, keterbatasan struktural, dan keterbatasan budaya.

Geopark sebagai model pengembangan pariwisata berbasis 
masyarakat dan sumberdaya lokal tentunya bukan tanpa hambatan. Potjana (2003) menyebutkan dalam pengem-bangan Community Based Tourism (CBT), bahwa dalam wisata berbasis masyarakat ada 7 prinsip yang harus dipatuhi pengelola, yaitu (1) pariwisata harus dikenali, didukung, dan dipromosikan sebagai milik masyarakat, (2) harus melibatkan masyarakat, mempromosikan keramahtamahan masyarakat, (4) meningkatkan kualitas hidup masya-rakat, (5) mengutamakan pelestarian lingkungan, budaya dan karakter masyarakat, (6) menghormati perbedaan budaya dan martabat manusia, (7) mendistribusikan manfaat-nya secara adil.

Makalah ini mengulas komunikasi pemasaran menggunakan saluran media sosial khu-susnya Facebook dan YouTube dalam memasarkan pariwisata geopark di desa Peniron.

Desa Peniron merupakan satu diantara 117 desa di kawasan Geopark Nasional Karang-sambungKarangbolong di Kabupaten Kebumen yang dinilai berhasil dalam pem-bangunan geopark geopark. Kementrian Perdesaan dan Daerah
Tertinggal Republik In-donesia, sebelum tahun 2015 desa Peniron merupakan desa pertanian yang tidak di-kenal, namun semenjak tahun 2016 pembangunan wisata geopark menjadikannya se-bagai desa wisata yang dikenal di tingkat nasional (Kemendesa, 2018). Kementrian tersebut mencatat komunikasi pemasaran dikembangkan oleh warga melalui saluran media sosial.

\section{PERUMUSAN MASALAH}

Tercapainya penjualan dalam wisata geoprak di desa Peniron tidak terlepas dari aktivi-tas komunikasi pemasaran yang dilakukan oleh warga setempat, dan penggunaan Face-book dan YouTube sebagai saluran komunikasi pemasaran. Bagaimana gambaran penca-paian tujuan pemasaran dan pemanfaatan media sosial dalam komunikasi pemasaran tersebut?

\section{METODE PENELITIAN}

Penelitian ini menggunakan metode kualitatif dengan pendekatan fenomenologi. Subjek penelitian adalah warga pelaku komunikasi pemasaran, yang membentuk pemaknaan mengenai geopark dengan latar belakang alamiah 
mereka, dan menyampaikan pemikiran atau gagasan mereka dalam memasarkan geopark ke wisatawan. Mereka melakukan seperti apa yang disampaikan oleh Bungin (2008), yaitu memiliki realitas yang dikonstruksi melalui tiga proses, yaitu proses internalisasi, objektivasi, dan ekster-nalisasi. Data dikumpulkan melalui wawancara semi terstruktur secara snowball kepada para informan yang menjadi kunci penelitian.

\section{TINJAUAN PUSTAKA}

Komunikasi pemasaran menurut Ulojimi Kayode dalam bukunya yang berjudul, "Fun-damentals of Marketing in Communication, Ed. 1" (2014) adalah komunikasi untuk berbagi informasi, konsep, dan makna tentang produk, layanan, dan organisasi yang menjualnya, oleh sumber dan penerima. Definisi lebih rumitnya adalah interaksi yang ditargetkan dengan pelanggan, dan prospek yang menggunakan satu atau lebih media. Sementara David Pickton dan Amanda Broderick dalam bukunya, "Integrated Mar-keting Communications, ed.2.”, (2014) menggambarkan

komunikasi pemasaran sebagai semua elemen promosi dari bauran pemasaran yang melibatkan komunikasi antara organisasi dan audiens tentang semua hal yang mempengaruhi kinerja pemasaran. Komu-nikasi pemasaran adalah bagian dari bauran pemasaran yaitu harga, tempat, produk, dan promosi (4P).

Dari pengertian-pengertian di atas diketahui bahwa dalam komunikasi pemasaran terjadi interaksi antara komunikator pemasaran dengan konsumen melalui bauran media sehingga terjadi kesamaan makna. Sebelum suatu produk diposisikan dalam benak pem-beli, maka pertama-tama harus diciptakan kesadaran melalui bauran promosi dengan se-demikian rupa sehingga pembeli mengembangkan sikap positif tentang produk dan perusahaan, sehingga menghasilkan penjualan.

Media sosial merupakan bentuk nyata dari media baru (Mayor (2010). Media baru ter-sebut mulai berkuasa setelah terjadi revolusi besar dalam teknologi komunikasi sejak akhir abad lalu, dan meningkatkan kekuatan komunikasi pemasaran, 
terlepas dari media tradisional seperti

TV, film, dan radio Ghosh (2016).

McConnell dan Huba (2007) (dalam

Charlesworth,

menggambarkan media sosial sebagai jumlah total orang yang membuat konten online, serta orang-orang yang berin-teraksi dengannya satu sama lain, dan merupakan elemen interaksi yang memberi alasan pada istilah dialog pemasaran. Media sosial merupakan sebuah kelompok aplikasi ber-basis internet yang dibangun berdasarkan fondasi ideologis dan teknologi web 2.0, yang memungkinkan terjadinya penciptaan, dan pertukaran konten yang diciptakan para penggunanya (Michael, 2010).

Dalam perkembangannya media sosial digunakan untuk komunikasi pemasaran. Charlesworth (2007) menyebut Social Media Marketing (SMM) sebagai istilah yang digunakan untuk mencakup strategi atau taktik pemasaran online yang menggunakan media sosial sebagai media komunikasinya. Media sosial menurut Castronovo (2012) bisa menjadi alternatif dalam komunikasi pemasaran dan sebagai komponen yang layak dari komunikasi pemasaran terpadu, layak untuk mengembangkan konseptual komunikasi pemasaran alternatif yang terintegrasi model yang dapat diterapkan industri untuk mencapai tujuan pemasaran.

Komunikasi pemasaran untuk destinasi wisata menurut Morrison (2015) adalah proses berkelanjutan dan berurutan dimana Destination Management Organization (DMO) atau organisasi manajemen tujuan wisata adalah merencanakan, meneliti, meng-implementasikan, mengendalikan dan mengevaluasi program yang bertujuan memuas-kan kebutuhan dan keinginan pelancong, visi, sasaran, dan tujuan dari organisasi mana-jemen tujuan wisata.

Menurut Morisson (2015) komunikasi pemasaran mewakili akumulasi semua kompo-nen dalam suatu merek bauran pemasaran yang mempromosikan pertukaran dengan membangun makna bersama dengan para pemangku kepentingan merek. Tujuan komu-nikasi pemasaran destinasi wisata adalah untuk menyediakan informasi untuk 
audiens atau wisatawan yang menjadi target, dan untuk mening-katkan penjualan wisata.

Dari penjelasan tersebut dapat dipahami bahwa komunikasi pemasaran untuk destinasi wisata membutuhkan manajemen perencanaan komunikasi pemasaran yang matang, dan terarah. Komunikasi pemasaran geopark merupakan komunikasi pemasaran geowisata berbasis masyarakat, terarah dan bersifat jangka panjang, bertujuan agar wisatawan da-tang berwisata setelah mengalami kesamaan makna dari saluran baruan media sosial.

Dalam panduan promosi Global Geopark UNESCO (UGG) diinformasikan bahwa se-cara internasional sudah ada kesepakatan antar anggota geopark global bahwa badan pe-ngelola geopark setelah menjangkau pasar geopark lokal, maka untuk selanjutnya harus mempromosikan geopark ke pasar nasional, dan pasar geopark internasional melalui jaringan pemasaran bersama. Berkait hal ini tentunya para pelaku komunikasi pemasa-ran geopark harus mempelajari dan memahami budaya negara asal wisatawan, dan me-mahami motivasi para wisatawan.

\section{HASIL DAN PEMBAHASAN}

Desa Peniro berjarak sekira 17 kilometer dari ibukota kabupaten Kebumen menuju ke arah utara berdekatan dengan perbatasan Kabupaten Banjarnegagara. Situs geologi di desa Peniron merupakan bagian dari 48 situs lain yang berada di wilayah geopark yang semenjak 28 Desember 2018 berstatus geopark nasional dengan nama Geopark Nasional KarangsambungKarangbolong. Kawasan geopark nasional tersebut memiliki luas $543.599 \mathrm{Km} 2$ dan mencakup 12 kecamatan.

Desa Peniron memiliki unsur atau elemen untuk mendukung penawaran sebagai desa wisata. Inskeep (1994) (dalam Fadila, 2017) mensyaratkan untuk mendukung pena-waran pariwisata ada tiga elemen yang harus ada atau dimiliki objek wisata. Elemen-elemen yang biasa dikenal dengan istilah triple $A$ 's, tersebut meliputi atraksi, aksesibilitas, dan amenitas. Elemen 
atraksi merupakan unsur objek wisata yang terdiri objek wisata yang bersifat tangible maupun intangible yang memberikan kenikmatan kepada wisatawan. Elemen atraksi dalam pariwisata terbagi tiga yakni atraksi alam, atraksi bu-daya, dan atraksi buatan.

Geopark di desa Peniron menawarkan atraksi alam yang berupa marfologi yang ada di gunung Brujul, yakni morfologi amphiteather yang puncaknya be-rupa batu-batu breksi andesit sisa pelapukan aktivitas gunung api purba pada zaman pra terzier yang terben-tuk sekitar 25 juta tahun yang lalu. Penamaan Brujul tidak terlepas dari banyaknya batu besar yang mbrujul atau keluar dari perut bumi. Atraksi alam lain adalah kesejukan hu-tan pinus tua seluas 100 hektar. Melalui puncak bukit Brujul para wisatawan bisa me-nikmati pemandangan yang luas dan indah terutama pada saat pagi dan sore hari.

Elemen penawaran amenitas adalah infrastruktur yang tidak langsung terkait dengan pariwisata tetapi sering menjadi bagian dari kebutuhan wisatawan. Elemen amenitas di desa Peniron diantaranya berupa pertunjukan kesenian dangsak atau hantu hutan, ebeg atau kuda lumping, barongan khas pegunungan, kesenian bernafaskan Islami Jamja-neng, rebana, dan sebagainya. Infratruktur lain berupa sarana permainan dan petua-langan seperti sepeda gantung, balon udara, flying fox, wisata camping, outbond dan se-bagainya. Produk makanan khas yang diantaranya hasil bumi dan produk olahan, oyek, lanthig, oseng teri, ikan. Cenderamata diantaranya kalung, gelang, tas, dari buah jenitri.

Elemen penawaran akesiebilitas di desa Peniron mencakup keseluruhan infrastruktur transportasi di Desa Peniron berupa jalan beton yang halus menuju lokasi. Jalan raya dari kota menuju terminal wisata, parkiran yang luas dan nyaman, warung makan, mu-shola semi permanen, dan jalan setapak untuk menyusur hutan pinus, batuan dan pun-cak yang bisa dilewati oleh wisatawan non petualang.

Pembangunan geopark desa Peniron dimulai pada tahun 2015. Awalnya warga merin-tis wisata petualangan Brujul Adventure Park di hutan pinus milik Perhutani di 
per-bukitan Brujul dengan bermodalkan dana desa sebesar $\mathrm{Rp} 50$ juta. Melalui pendekatan partisipatif dan proses dialogis, potensi konflik yang ada dikonversi menjadi modal sosial untuk membangun geopark. Untuk menarik minat wisatawan BUMDES Sumber Makmur selaku badan pengelola menawarkan harga tiket masuk lokasi wahana yang relatif murah yaitu Rp 3.000, parkir sepeda motor Rp 1.500, dan parkir mobil Rp 5000.

Melalui pembangunan wisata geopark tersebut masyarakat Desa Peniron memperoleh keuntungan ekonomi dengan menjadi pengelola, pemandu, instruktur geopark, me-ngembangkan usaha seperti homestay, warung makan, berjualan cenderamata, jasa ojek dan biro perjalanan. Pemerintah desa Peniron mencatat dalam rata-rata sebanyak 1500 wisatawan datang berkunjung ke desa Peniron dalam setiap bulan. Selama musim libur lebaran tahun 2018 tercatat sebanyak 15000 wisatawan mengunjungi Desa Peniron.

Dalam catatan Kementrian Pembangunan Desa dan Daerah Tertinggal, unit usaha BUMDES
Sumber Makmur Brujul Adventure Park meraih pemasukan sebesar Rp 150 juta setelah dua tahun berjalan. Taufik Hidayat menuturkan para pekerja di lokasi wisata mendapatkan honor masing-masing sebesar Rp 70 ribu per hari, berdasarkan pada hari berangkat kerja. BUMDES bisa menyetorkan uang hasil sisa pengelolaan ke masyarakat melalui mekanisme PADes.

Keberhasilan pencapaian tujuan pemasaran tersebut mendorong warga untuk memba-ngun lagi secara bertahap 3 objek wisata baru setelah Brujul Adventure Park. Sampai dengan tahun 2020 berhasil dibangun wahana Wisata Agro Kebun Kelengkeng, Taman Bunga Banyu Langit, dan Wisata Embung.

Keberhasilan Desa Peniron di atas tidak terlepas dari kemampuan masyarakat setempat dalam menyiapkan jasa wisata geopark dan memasarkannya pada para wisatawan baik lokal maupun nasional. Para wisatawan tertarik untuk datang berwisata setelah sebelumnya mereka memahami makna pesan pemasaran dari warga, kemudian me-ngalami perubahan sikap dari tidak 
mengetahui sampai dengan memutuskan untuk datang berwisata. Para wisatawan bersedia menginap selama beberapa hari untuk be-lajar geologi, biologi atau budaya setempat.

Sesuai konsep geopark sebagai antitesa pariwisata massal, para wisatawan yang semula hanya singgah sejenak pada akhirnya mulai menginap di desa, menggunakan jasa para pemandu wisata, memperoleh pengetahuan geologi, biologi, dan budaya, membeli geo-food, geo product seperti kerajinan jenitri, dan sebagainya, sehingga berimpak pada sosial ekonomi masyarakat, menumbuhkan konservasi alam dan pembangunan berke-lanjutan di desa Peniron.

Penggunaan media sosial dalam membangun komunikasi pemasaran geopark tidak ter-lepas dari adanya beberapa keterbatasan di Desa Peniron. Sebagaimana umumnya desa-desa pelosok di pegunungan, desa Peniron memiliki keterbatasan seperti infrastruktur jalan yang sempit, teknologi komunikasi dan informasi serta persoalan kemiskinan pe-desaan. Jalan menuju lokasi yang terbilang kurang lebar dan berkelok seringkali di-perburuk oleh kerusakan meskipun selalu ada perbaikan setiap tahun anggaran.

Akses masyarakat ke media massa tradisional dan akses media baru tidak sebaik dan se-mudah masyarakat yang tinggal di perkotaan meskipun teknologi internet dan piranti pendukungnya seperti komputer dan smartphone sudah banyak dimanfaatkan oleh pen-duduk setempat. Beberapa operator seluler umumnya melayani masyarakat dengan baik. Hanya pada area tertentu penerimaan sinyal sangat lemah, bahkan blankspot sama sekali karena terhalang perbukitan dan alam pegunungan. Untuk menangkap siaran televisi banyak yang menggunakan piranti parabola. Media cetak koran tidak ada pelanggan.

Hambatan yang lain dalam mengembangkan komunikasi pemasaran geopark adalah ketersediaan SDM yang sesuai kebutuhan komunikasi pemasaran menguasai pengetahuan, keahlian komunikasi yang memadai, dan memahai strategi komunikasi. Selain itu menguasai 
pembuatan isi pesan sesuai dengan audiens atau wisatawan yang dituju, sa-luran komunikasi beserta seluk beluknya. Pelaku komunikasi pemasaran geopark Desa Peniron sebagian adalah pemuda dari keluarga berlatar belakang petani. Meskipun ber-kesempatan menempuh pendidikan formal yang tinggi di kota lain bukan untuk belajar komunikasi dan pemasaran. Praktis untuk menyesuaikan dengan kebutuhan komunikasi pemasaran tersebut mereka harus mempelajarinya secara mandiri atau otodidak melalui bergama cara termasuk melaui media internet.

Dalam menjalankan fungsi komunikasi pemasaran, akun Facebook Peniron News menayangkan cerita wisata berbasis peristiwa dalam bentuk teks, foto dan video flash di halamannya. Informasi berupa cerita wisata tersebut juga dibagi atau diunggah melalui akunakun personal lainnya. Para penulis atau pencerita di halaman Facebook tersebut adalah warga setempat. Mereka terlibat dalam pengelolaan wahana Brujul Adventure Park. Para pengelola geopark tidak menyewa jasa agensi para komunikator pemasaran profesional.

Para pelaku komunikasi pemasaran geopark yang merupakan warga desa Peniron tidak memasang iklan atau menggunakan media sosial secara berbayar di Facebook.. Cerita yang diunggah di Facebook tidak didaftarkan sebagai cerita bersponsor, dengan de-mikian sesuai kebijakan Facebook tidak membidik segmen tertentu sesuai target pema-saran, akan tetapi sebatas mengikuti jejaring sosial yang dimiliki oleh pemasar. Praktis Facebook hanya digunakan untuk menginformasikan kegiatan di objek wisata, atau hanya cerita seputar kegiatan masyarakat, dan potensi desa di halaman sosial Facebook tanpa bayar. Cara penayangan tersebut membuat terhindar kebijakan laman Face-book yang berbayar. Selain memiliki kebijakan tidak berbayar, Facebook menerapkan kebijakan laman berbayar.

Adanya keterbatasan untuk mengembangkan promosi geopark para komunikator mengakalinya secara kreatif, diantaranya dengan cara rajin dan rutin menulis 
cerita atau storytelling. Hal ini terlihat dari banyak unggahan warga berupa cerita atau storytelling di laman Facebook tanpa bayar dengan konten yang beragam. Konten tersebut dianta-ranya seputar geologi, event kegiatan yang akan digelar, sejarah desa, mitos yang diya-kini, tradisi lisan, bermacam kesenian, dan seputar sistem pengetahuan atau kearifan lokal lokal yang lebih luas yang mereka miliki sebagai warisan "unik" dari turun temu-run dari leluhur mereka.

Selain menggunakan saluran Facebook, BUMDES Sumber Makmur memanfaatkan YouTube untuk saluran komunikasi pemasaran. Kanal video tersebut biasanya mena-yangkan video-video berisi objek wisata, lanskap dan kegiatan masyarakat di desa Peni-ron, terutama kegiatan yang mendukung geopark seperti kesenian, atau kearifan lokal setempat lainnya. Video juga diunggah oleh para pengunjung Wahana Brujul Adventure Park. Badan resmi lain yang mengunggah video adalah Dinas Pemuda Olah Raga dan Pariwisata Kabupaten Kebumen dengan video berjudul, "Brujul
Adventure Park Kebu-men Drone View".

Video-video yang diunggah di media sosial sebagian besar yang memproduksi para vi-deographer non profesional atau amatir, dan umumnya para pehobi. Mereka secara sukarela merekam gambar wisata untuk kebutuhan pembuatan vlog pribadi misal video So Iman berjudul,"Taman Wisata Brujul Adventure Park". Vlog Permana Yogi yang berjudul, "BARUU!! Taman SERIBU BATU, Wisata Alam Bukit Brujul Kebumen". Untuk konten seni tradisi ada YouTuber bernama, Sumbogo Nur Aji yang mengunggah video, "Peresmian Wisata Brujul Adventure Park-Ebeg Langen Budaya Perkutukan, dan Dangsak Peniron-Randu Budoyo."

Video juga dibuat oleh para mahasiswa UMP Puworejo yang menempuh studi KKN di Desa Peniron. Awalnya video mereka produksi untuk laporan kegiatan $\mathrm{KKN}$, kemudian mereka unggah di YouTube dengan judul, "Profil Desa Peniron". Komunitas siswa multimedia Bekasa Studio SMK Bhina Karya Karanganyar 
mengunggah video praktek mereka yang berjudul Brujul Adventure Park Peniron Kebumen. Materi yang diunggah di YouTube kebanyakan bersifat informatif, ala juranlistik warga tanpa pesan penjualan.

Pengembangan geopark desa Peniron mendapatkan peliputan media massa online, me-dia massa tradisional yaitu media cetak dan media TV. Beberapa stasiun TV menjadi-kan desa Peniron menjadi lokasi produksi program dokumenter petualangan. Misalnya Trans TV memprodukis program My Trip My Adventure, My Trip My Adventure Kidz, Selebritis On Vacation, dan produksi feature TV oleh Metro TV, I News TV, dan NET TV. Selain siarkan di kanal TV masing-masing, dokumenter dan feature program yang diproduksi media TV tersebut disiarkan oleh pihak pengelola stasiun TV melalui salu-ran YouTube dengan judul yang sama atau diganti kata kuncinya dengan maksud terten-tu, selayaknya target viral.

Bagi pihak stasiun TV, informasi atau cerita-cerita yang ditayangkan di media sosial menjadi sumber inspirasi awal sebelum melakukan riset lapangan untuk mengumpulkan bahan memproduksi program siaran. Para produser TV biasanya meminta informasi secara interaktif dengan pengelola geopark sebelum membuat desain produksi.

Program pariwisata di TV umumnya bersifat good news, dan diproduksi oleh para pro-fesional dengan standar produksi dan standar teknologi broadcast internasional, se-hingga secara kualitas lebih baik dibandingkan video yang diproduksi oleh para vloger atau YouTuber. Program dokumenter atau feature TV yang bersifat good news tersebut umumnya mengusung spirit turism orang kota terutama yang memiliki daya beli pada produk para sponsor program dan tentunya memiliki kebutuhan berwisata. Kenyataan tersebut kiranya menguntungkan warga, karena menjadi sarana promosi melalui media tradisional tanpa harus mengeluarkan biaya, untuk memproduksi, dan membeli durasi untuk penayangan sebagaimana tradisi ekonomi media tradisional. Adanya penayangan video bersumberkan program TV di YouTube membuat jumlah video 
geopark desa Pe-niron yang masih sedikit menjadi bertambah dan audiens di kanal YouTube bertambah.

Menurut Taufik Hidayat banyaknya jumlah materi pemasaran yang diunggah oleh ba-nyak pihak melalui Facebook dan You Tube terutama tentang geosite Brujul Adventure Park, potensi alam, pertanian, budaya di sekitar geosite, yang berupa pesan teks, foto, dan video yang diunggah secara berulangkali menumbuhkan rasa penasaran wisatawan sehingga memutuskan untuk mencari tahu lebih banyak dengan mendatangi destinasi. Ini terlihat dari interaksi, berupa klik, tanda like, dan aktivitas tanya jawab antara penge-lola geopark dengan wisatawan.

Selain menggunakan saluran Facebook, dan YouTube, komunikasi pemasaran geopark menggunakan media baru seperti blog, dan Instragram. Media blog berisii nformasi wisata dan kegiatan warga. Media cetak berupa brosur dan leaflet juga menjadi saluran. Media cetak ini berisikan tawaran paket-paket atraksi wisata, akomodasi, harga tiket, se-wa hom stay, sewa tenda, dan sebagainya.

\section{Efektifitas penggunaan Facebook dan} YouTube sebagai saluran komunikasi dalam me-masarkan geopark di desa Peniron tidak pernah diukur secara ilmiah, atau dilakukan pengukuran secara khusus. Namun pengelola geopark melihat dan merasakan efeknya terutama dengan bertambahnya jumlah pengunjung dari waktu ke waktu. Biasanya mereka memulai pengukuran dengan melihat dari interaksi dan dialog yang terjadi di Facebook yang menandakan ada penambahan anggota komunitas, dan ketertarikan orang untuk datang. Pengunjung pada umumnya menanyakan tentang lokasi, penyelenggaraan event, transportasi jika bertandang, penginapan, termasuk pengunaan apli-kasi seperti ojek online, grab, dan traveloka, atau mempertanyakan lebih lanjut informasi geopark yang ditayangkan di Facebook, media TV, dan YouTube sebelumnya. Al-hasil, geopark desa Peniron menjadi perbincangan dari mulut ke mulut, selain diramai-kan selfi, dan vlog wisatawan di media sosial. Tingginya kunjungan wisatawan dan ber-tambahnya objek 
wisata baru menunjukan adanya efek dari komunikasi pemasaran yang dilakukan.

\section{PEMBAHASAN}

Temuan-temuan tersebut diatas menarik untuk diskusikan lebih lanjut terutama berkait gambaran peran Facebook dan YouTube, dan media tradisional televisi sebagai bauran saluran komunikasi pemasaran gropark. Terlebih lagi target pemasaran geopark wisata-wan lokal, nasional dan internasional. Pada kenyataannya bahwa media sosial berupa Facebook dan YouTube banyak digunakan oleh masyarakat desa Peniron dan desa pegunungan di sekitarnya. Media baru tersebut mereka gunakan dengan menggunakan piranti media internet, dan smart phone mobile yang berbasis aplikasi android. Menggunakan media sosial tersebut warga berhubungan antarsesama, dan dengan lingkungan dunia di luar desa mereka, ter-masuk untuk saluran komunikasi pemasaran geopark di desa Peniron.

Dari temuan diatas diketahui bahwa keputusan memilih Facebook tidak terlepas dari sifat dua media sosial tersebut yang kekinian, dan jumlah penggunanya semakin ba-nyak, penggunaannya mudah, bahkan seiring berkembangnya teknologi informasi dan komunikasi, mengunggah isi dan melakukan interaksinya bisa dari desa.

Berdasarkan data Kompastekno tahun 2018, pengguna layanan Facebook jumlahnya mengalami peningkatan pada tahun 2018. Lembaga We Are Social dan Hootsuite dalam laporan digital tahunan melaporkan pertumbuhan sosial media pada tahun 2018 mencapai 13 persen dengan jumlah pengguna total mencapai 3 miliar. Angka tersebut menunjukan bahwa penggunaan Facebook masih mendominasi dengan jumlah pengguna aktif Facebook pada tahun 2018 lebih dari 2,17 miliar pengguna, atau menguasai dua pertiga pasar dunia. Tekno.kompas (2018) menyebut jumlah tersebut naik hampir 15 persen dibandingkan tahun sebelumnya. Jumlah pengguna Facebook Indonesia menem-pati urutan terbesar keempat global. 
Keputusan memilih YouTube sebagai tool komunikasi pemasaran, pertama, mempertim-bangkan jumlah penguna YouTube dan kegunaannya. Foye (2018) menyatakan YouTube merupakan salah satu saluran komunikasi paling menonjol dengan anggaran tinggi yang ditetapkan untuk tujuan komunikasi pemasaran yang ditargetkan pada kelompok usia 18-34 tahun. Menurutnya bentuk media sosial paling populer untuk kelompok usia ter-sebut adalah video digital dengan perkiraan jumlah pengguna global ada 4,5 miliar, dan proyeksi pengeluaran iklan sebesar \$ 37 miliar pada tahun 2022 untuk semua platform berbagi video. Kirakira seperempat dari pengeluaran iklan yang diproyeksikan itu dipertanggungjawabkan ke YouTube, menghabiskan lebih dari 1 miliar jam penayangan video per hari.

\section{YouTube Analytics Basics 2018} menuliskan secara global, YouTube adalah mesin pen-cari yang paling banyak digunakan yang kedua setelah Google, dan merupakan situs web ketiga yang paling banyak dikunjungi, dan situs pembuatan dan pembuatan sub-stansi video utama. YouTube menawarkan keanggotaan gratis, mengunggah dan/atau melihat konten yang mengarah ke popularitas besar di kalangan pengguna media sosial. Ada sekitar 1,5 miliar orang menggunakan YouTube setiap bulan, di mana dua pertiga berada di kelompok usia 18-44. Lebih dari 400 jam video diunggah per menit, 1 miliar jam konten video ditonton per hari.

\section{YouTube Official Blog (2015)} menyebutkan bahwa pada kurun 10 tahun, konten selama 300 jam diunggah ke YouTube setiap menit, dan konten YouTube yang mencengangkan karena 1 miliar jam atau 100.000 tahun saat ini sedang ditonton setiap hari di seluruh dunia (Goodrow 2017).

Pertimbangan lain untuk memilih saluran Facebook dan YouTube adalah kenyataan bahwa dua media sosial tersebut pada saat sekarang ini telah bergeser fungsi dari media sosial menjadi media komunikasi pemasaran. Menurut penelitian Kevin Curran, Sarah Graham, dan Christpher Temple pada tahun 2011 yang berjudul, "Advertising on Facebook", menemukan bahwa pendekatan untuk periklanan telah 
berubah secara dramatis selama 50 tahun terakhir dengan bergeser ke media sosial..."

Pergeseran fungsi media sosial menjadi media pemasaran juga terjadi di YouTube. Me-nurut Reino (2017), YouTube yang dimulai sebagai alat media sosial, tetapi sekarang berkembang menjadi alat komunikasi pemasaran. YouTube yang sejak didirikan pada tahun 2005, keberadaan dan dianggap sebagai situs berbagi video terbesar, telah menga-lami perubahan besar selama dekade terakhir, oleh karena platform ini berkembang menjadi alat pemasaran terkemuka yang digunakan untuk promosi produk oleh influen-cer media sosial (Schwemmer, 2018).

Oleh karena adanya pergeseran fungsi pada dua media sosial tersebut, Temple.et.all., (2011) menyarankan agar pemasar yang menggunakan saluran media Facebook mempertimbangkan bentuk lain dari pemasaran yang akan menjangkau target pelanggan de-ngan cara baru oleh karena adanya paksaan tersebut. Berkait pergeseran fungsi dari YouTube, menurut Smith (2018), banyak organisasi komunikasi pemasaran memanfaat-kan YouTube, terutama untuk memperoleh wawasan yang lebih baik tentang kecenderungan perilaku konsumen di masa depan, karena meningkatnya daya beli kaum muda, dan fakta bahwa lebih dari $80 \%$ dari mereka pergi ke YouTube setiap bulan.

Berkait penggunaan media sosial sebagai saluran komunikasi pemasaran geopark dia-tas, maka sebagaimana pendapat Fatchiya (2017), bahwa meningkatnya pengguna me-dia sosial menjadi peluang besar bagi pelaku bisnis termasuk bisnis pariwisata yang berbasis masyarakat. Sedangkan menurut Tisa (2019,) media sosial sering digunakan oleh pengelola kawasan wisata, termasuk untuk mempromosikan objek wisata yang dimiliki oleh setiap daerah di era digital saat sekarang ini. Semua itu oleh karena pertimbangan media sosial lebih mudah dalam penggunaan, hemat biaya, dan efektif dalam pemasaran sehingga sangat membantu dalam pengembangan pariwisata terutama di daerah. 
Warga dengan bermacam keterbatasan yang ada memutuskan saluran Facebook dan YouTube untuk membangun komunikasi pemasaran geopark. Meskipun pilihan tersebut memberi beberapa kemudahan solusi di tengah keterbatasan yang ada, sebenarnya pilih-an tersebut bukan tanpa resiko atau kelemahan berkait dengan efektifitas dan pencapai-an tujuan komunikasi pemasaran, meski ini masih membutuhkan penelitian lebih lanjut.

Pada kasus Facebook pilihan mempromosikan geopark terutama dengan memanfaatkan halaman Facebook yang sifatnya cuma-cuma atau tanpa bayar, sebenarnya luas jang-kauan komunikasi pemasarannya hanya sebatas pada jaringan sosial atau pertemanan sang pemilik akun. Hal tersebut berbeda dengan Facebook yang berbayar, dimana jang-kauan audiens bisa disesuaikan harga atau besar sponsorship yang dibayarkan, yang disesuaikan dengan kebutuhan pemasar, dan target audiens, serta kebijakan pengelola

Facebook. Charlesworth (2007) menyebutkan bahwa pemasaran dengan media sosial dapat mencakup iklan di situs media sosial, dan ini lebih umum digunakan dalam konteks pemasaran viral atau optimasi media sosial. Dari penjelasan tersebut diperoleh pe-ngertian bahwa untuk mencapai tujuan optimasi pemasaran tentu konten di media so-sial harus diviralkan, termasuk dengan memanfaatan kebijakan tayang dengan berbayar.

Bahwa laman Facebook berbeda dengan laman iklan. Atas hal ini pendapat Weber dan Srinivasa harus diperhatikan oleh para komunikator pemasaran. Menurut Weber (2009) Facebook adalah jenis media sosial, dimana orang-orang dengan minat yang sama berbagi ide, dan komentar dalam lingkungan virtual, sedangkan iklan menurut Srinivasa (2008) didefinisikan sebagai berbagi informasi tentang produk dengan cara non-pribadi biasanya dibayar oleh sponsor melalui media yang berbeda. Senada definisi tersebut, se-belumnya Sriniuva, Ayanwala, et.al., (2005) mendefinisikan iklan sebagai bentuk ko-munikasi berbayar nonpribadi, dimana ide, konsep, produk atau layanan, dan infor-masi, dipromosikan melalui media (visual, verbal, dan teks) oleh sponsor yang 
diidenti-fikasi untuk membujuk atau mempengaruhi perilaku.

Iklan Facebook menurut Sendberg (2010) memungkinkan pelanggan berbagi penga-laman, ide, minat, dan informasi bermanfaat tentang suatu merek. Iklan Facebook ber-manfaat karena sangat membantu dalam mengumpulkan umpan balik, dan informasi de-mografis pelanggan yang ditargetkan. Goldsmith \& Lafferty, (2002) menyatakan bahwa di lingkungan bisnis saat ini, iklan Facebook adalah sumber yang efektif untuk men-jangkau pelanggan yang ditargetkan. Selain itu iklan Facebook memberikan kesempatan untuk membangun merek dan terlibat dengan pelanggan di jejaring sosial besar.

Penemuan kasus serupa terdapat dalam penggunaan YouTube sebagai saluran komuni-kasi pemasaran. Kebijakan iklan atau mengunggah konten dengan berbayar juga menjadi kebijakan juga diberlakukan oleh YouTube. Ada banyak alat komunikasi pemasaran yang ditawarkan oleh YouTube termasuk display, overlay, penemuan pencarian, kartu disponsori, video, dan bumper (Manetti dan Bellucci, 2016) yang memberikan garis be-sar YouTube yang komprehensif sebagai platform komunikasi pemasaran. Untuk kesa-daran dan paparan yang lebih luas, YouTube menawarkan promosi berbayar dan berbagi konten video yang tidak hanya hemat biaya, tetapi juga berdampak cepat.

Target jangkauan audiens pada iklan YouTube yang berbayar lebih luas daripada laman yang tanpa bayar. Leonhardt (2015) dalam paper "Going Viral On Youtube" me-nyampaikan belajar dari beberapa iklan di YouTube yang menjadi viral dan dengan cepat menjangkau jutaan konsumen, dan dari beberapa kesamaan diamati, seperti bahwa setiap iklan membangkitkan emosi yang kuat, menceritakan sebuah kisah, dan dengan cepat mencapai satu juta tampilan. Kesimpulan Leonhardt, bahwa saat mempromosi-kan konten merek di YouTube, para manajer didesak untuk fokus mempromosikan kon-ten yang sangat emotif, untuk memasukan merek ke dalam cerita, dan untuk terus mem-produksi dan mempromosikan konten merek baru. Karakteristik iklan tertentu seperti 
bercerita dan emosi menakutkan dapat mempengaruhi kemungkinan viralitas iklan. Dengan demikian karaktersitik iklan seperti diatas, meskipun memiliki jangkauan yang luas, jangkauannya akan semakin luas bila diunggah secara berbayar.

Berkait adanya peran serta media TV dalam bauran komunikasi pemasaran geoparks, perlu dipertimbangkan efektifitasnya. Memasuki era kekuasaan media baru sekarang ini, media TV yang notabene merupakan saluran media konvensional, masih banyak pe-mirsanya di Indonesia. Namun demikian kemampuan media TV untuk menarik perha-tian penuh dari pemirsa diragukan. Penelitian Triwardani (2012) menemukan adanya praktik beraktivitas jamak pemirsa televisi yang saling terkait dengan tanggungjawab dan tugastugas rutin yang tidak selalu berhasil merebut perhatian pemirsa, bahkan pada acara televisi pilihan yang dipilih untuk ditonton mereka. Praktik aktivitas jamak terse-but misal berkait kerumahtanggaan seperti, membersihkan rumah, mencuci, memasak, makan, ngobrol, SMS-an, dan sebagainya. Bahkan beberapa aktivitas yang dilakukan oleh pemirsa sama sekali tidak mengindahkan apa yang ada di layar televisi, misalnya membaca, mengerjakan tugas kuliah, menerima panggilan telelepon, internetan, bahkan sambil tidur. Menonton tayangan televisi sekedar menjadi aktivitas sambilan.

Berkait penayangan dokumenter dan feature program yang diproduksi media TV di sta-siun dan di YouTube dan bisa dipahami bahwa bagi pihak stasiun TV saluran YouTube menjadi saluran yang berguna untuk memperluas jangkauan pemirsa karena YouTube merupakan media video interaktif global, sekaligus potensi sumber penghasilan baru ba-gi stasiun TV, seiring tingginya jumlah viewer dan subscriber. Namun lagi-lagi optimasi pemasaran sulit bila jumlah pengunjung belum memenuhi target dan/atau viral.

Berkait perusahaan atau pribadi yang ingin menjadikan YouTube sebagai sumber pen-dapatan, penelitian Ahmad (2019) perlu menjadi pertimbangan, bahwa untuk menghasilkan uang dari YouTube, saluran membutuhkan kelayakan 4.000 jam tonton dalam 12 bulan terakhir, dan 
memiliki pelanggan minimal sebanyak 1.000 orang, dan waktu menonton video harus 30 detik. Hasil penelitian Wijayanto, (2016) menunjukkan bahwa tingkat penghindaran iklan di Indonesia mencapai $23 \%$, relatif sama dengan penelitian lain di berbagai negara. Hasil uji hipotesisnya juga menunjukan hubungan yang signifikan antara penghindaran iklan, dan variabel demografis, atribut iklan, dan kompetisi yang mempengaruhi penghindaran iklan. Dengan demikian pemasukan lewat bagi hasil iklan bagi pemasang konten, dan optiamsi audiesn menghalami hambatan.

Efektifitas komunikasi menurut Engel (dalam Hurriyati, 2008) diukur dalam tiga unsur yaitu kognitif, afeksi, dan konatif. Bila menggunakan ukuran ini, maka komunikasi pe-masaran geopark desa Peniron dapat dikatakan telah dapat membentuk kesadaran informasi tertentu (efek kognitif) pada para pelaku wisata khususnya wisatawan, mem-berikan pengaruh untuk melakukan sesuatu dalam hal ini tentunya memutuskan untuk datang berwisata (efek afeksi), dan memunculkan perilaku pembentukan pola khalayak menjadi perilaku selanjutnya berupa kunjungan ke geopark yang berulang (efek konatif). Ukuran itu terbukti dengan melihat wisatawan yang datang berwisata dan jumlahnya te-rus bertambah, meskipun mayoritas lokal dan wisatawan dalam negeri. Jumlah wisata-wan yang berwisata juga menjadi pertimbangan penambahan wahana wisata baru.

Castronovo (2012) dalam makalah berjudul, "Social Media in an Alternative Marketing Communication Model", menekankan bahwa untuk mengetahui pencapaian tujuan pemasaran, kekuatan program media sosial yang efektif harus diukur. Salah satu yang da-pat dilakukan dengan terus menilai tingkat dialog dan keterlibatan di antara anggota. Menurut Castronovo, efektivitas program pemasaran media sosial harus diukur dalam hal kemampuannya untuk menghasilkan buzz positif tentang perusahaan, serta produk dan layanannya, dan harus diterjemahkan ke dalam hasil bisnis yang terukur untuk peru-sahaan, baik dalam bentuk peningkatan kesadaran, 
peningkatan penjualan, atau loyalitas konsumen sesuai dengan tujuan komunikasi pemasaran yang dikembangkan oleh perusahaan. Berbeda dengan Castronovo, menurut Dwyer, (2007) keefektifan media sosial tidak hanya diukur dalam hal volume buzz,WOM, melainkan, dari pentingnya, dam-pak, dan tingkat keterlibatan komunikasi WOM yang diukur jika harus kuantitatif.

Pengukuran aspek interaktif disampaikan pula oleh Stewart dan Pavlou (2002) menje-laskan bahwa dalam konteks interaktif, mengukur struktur interaksi sangat penting untuk menilai program media sosial. Sedangkan metrik eksposur seperti klik tayang harga, biaya per klik, jumlah klik, dan lalu lintas situs Web adalah cara untuk mulai memahami seberapa baik program bekerja, hasil yang berhubungan dengan interaksi yang me-nambah nilai dan kualitas bagi interaksi pemasar konsumen juga menjadi fokus dalam pengukuran (Stewart, et, all. 2002).

Kaldeen (2019) mengutip YouTube Analytics Basics (2018) menjelaskan kemanjuran YouTube sebagai platform komunikasi pemasaran dapat dinilai me-lalui kliktayang tingkat tampilan, penayangan video yang selesai dan/atau jumlah share, dan jumlah komentar dan suka. Ukuran lain untuk penilaian adalah penarikan iklan, keterlibatan serta pemahaman dan umpan balik melalui ulasan konsumen, yang mengungkapkan sentimen umum terhadap komunikasi pemasaran suatu merek yang pada gilirannya mempengaruhi masa depan perilaku pembelian audiens. Selain itu, wawancara kualita-tif, analisis konten dan/atau survei sikap juga dapat digunakan untuk menilai efektivitas komunikasi pemasaran dengan memeriksa afektif tanggapan terhadap komunikasi pe-masaran YouTube.

Berkait penggunaan YouTube untuk komunikasi pemasaran pariwisata, pernyataan Reino (2017) berkait YouTube layak diperhatikan, terutama milihat YouTube sebagai alat pemasaran pariwisata dari sudut pandang organisasi pariwisata dan wisatawan, yang menurutnya membuat banyak organisasi gagal memahami untuk apa media pemasaran diproduksi outlet tradisional (TV, bioskop) tidak dapat ditransfer 
langsung ke YouTube. Menurutnya, dari peristiwa tersebut kekuatan yang berkembang justru dari konsumen individu dalam pemasaran pariwisata, tercermin sebagaimana dalam dominasi video pariwisata yang diproduksi oleh turis sungguhan daripada oleh organisasi pariwisata resmi.

Pada kasus komunikasi pemasaran geopark di Desa Peniron, video selain diunggah oleh warga, BUMDES, dan lembaga resmi Dinas Pariwisata Pemuda dan Olah Raga Kabu-paten Kebumen, video diunggah pula oleh para wisatawan melalui vlog-vlog mereka. Untuk mengetahui efektifitas YouTube masih perlu penelitian lain. Perlu menjadi cata-tan bahwa video Brujul Adventure Park yang diunggah dinas Diporwisarta pada 18 Mei 2017 silam sampai saat ini baru $8.262 \mathrm{x}$ ditonton. Jumlah penonton tersebut masih dibawah video yang diunggah warga, dan vlog-vlog wisatawan. Sebagaimana pendapat Reino, unggahan video para wisatawan adalah energi tambahan yang bersifat cuma-cuma pada lama tanpa bayar.

Hosanagar (2018) yang mempelajari hubungan berbagai jenis konten pemasaran media sosial dengan keterlibatan pengguna, menunjukkan bahwa ada manfaat untuk rekayasa konten, yang menggabungkan karakteristik informatif yang membantu dalam menda-patkan arahan langsung, seperti harga dan transaksi, dengan konten yang terkait dengan kepribadian merek, seperti humor dan emosi, yang membantu mempertahankan jang-kauan dan pencitraan merek di masa depan di situs media sosial melalui peningkatan keterlibatan. Hasilini menginformasikan pentingnya strategi desain konten.

Langkah para komunikator pemasaran di desa Peniron memilih halaman Facebook tan-pa bayar atau cuma-cuma tersebut berbeda dengan yang ditempuh oleh perpustakaan akademi di Hongkong. Sebagimana dalam penelitian Chan (2012) yang menyelidiki efektivitas relatif beberapa pendekatan berbeda untuk iklan Facebook di perpustakaan Akademi Hongkong sebagai novelty dari penelitian yang ada sebelumnya yang pada umumnya menyarankan iklan online menjadi cara yang hemat biaya untuk mencapai tu-juan. Setelah menganalisis beberapa kampanye iklan yang dilakukan oleh 
perpustakaan

tersebut,

menyimpulkan bahwa iklan jejaring

sosial efektif mempromosikan perpusta-kaan dengan biaya keuangan yang sangat kecil, menyebabkan perpustakaan menjadi lebih banyak dipertimbangkan audiens sehingga jumlah pengguna perpustakaan tersebut menjadi bertambah. Iklan dengan jejaring sosial tersebut oleh pengelola perpustakan tersebut digunakan untuk melengkapi media pemasaran yang ada.

Namun jika perusahaan tidak ada anggaran dan memutuskan memanfaatkan laman tan-pa bayar, tips pengelola Facebook ini layak dipraktekan. Dalam sebuah edisi edukasi tentang dasar-dasar membuat strategi pemasaran dan promosi di Facebook agar cepat laku, pihak pengelola Facebook menjelaskan bahwa ada beberapa tips dalam berjualan di Facebook agar omset penjualannya tinggi. Tips yang pertama, tentukan produk; ke-dua, bidik target penjualan, ketiga; tentukan waktu mengunggah yang tepat; keempat, optimasi fanspage, group, akun Facebook; kelima, hindari "tag marketing" berlebihan (Facebook.com, 2014).
MIX Marketing Communication (2014) menginformasikan bahwa Facebook menghar-gai cerita (storytelling) oleh karena cerita yang bagus seringkali merupakan konten yang bagus, dan harus dipastikan bahwa konten tersebut mengagumkan. Hal ini dikarenakan Facebook secara berkala melakukan perubahan alogritma. Pada prinsipnya jika konten yang dibuat dan diunggah berada pada deretan teratas, dan bisa dipastikan keasliannya, serta mampu menceritakan tentang hal yang menarik, maka akan memastikan hal terse-but tetap dapat membuat konten tetap menjadi terlihat, sekalipun anggaran komunikasi pemasaran sebenarnya tidak memungkinkan untuk menyewa Facebook Advertising, atau produsen tidak mau mengeluarkan uang untuk membuat konten menjadi terlihat.

Untuk mencapai kesuksesan jangka panjang di YouTube pengamatan Reinhard (2009) menemukan bahwa upara pemasar harus secara konsisten dan sering menerbitkan kon-ten yang menyegarkan yang memiliki nilai intrinsik untuk pemirsa online, bisa menjadi rekomendasi bagi para pelaku komunikasi pemasaran 
pariwisata. Pertanyaan sederhana yang bisa diajukan dalam konteks komunikasi pemasaran geopark ini adalah seberapa sering tema geopark dieksplorasi, diproduksi, diunggah, menjadi viral, dan memperluas jangkauan komunitas dan optimasi komunikasi pemasaran, bagaimana karakteristiknya, cara mengunggahnya di media sosial, berbayar atau tidak berbayar.

\section{KESIMPULAN}

Pemilihan penggunaan Facebook dan Youtube sebagai saluran komunikasi pemasaran geopark yang partisipatif di Desa Peniron adalah untuk menyesuaikan perkembangan zaman di mana media tradisional telah digeser ke media baru, selain adanya keterbata-san dalam pengembangan komunikasi pemasaran. Dua media sosial tersebut digunakan secara tanpa bayar, dan menjadi bauran komunikasi dengan media pemasaran tradisio-nal terutama televisi. Untuk optimasi komunikasi pemasaran, warga secara kreatif mengembangkan cerita atau storytelling, dan menghindari tool kebijakan iklan atau ber-bayar dari Facebook dan YouTube. Bahwa storytelling yang kreatif mengagumkan, dan konten berkarakteristik tertentu bisa menjadi solusi di dua media sosial tersebut. 